\title{
Invaginação Basilar com o Processo Odontóide, Localizado acima do Bordo Posterior do Clivus, Causando Deformidade na Face Anterior da Medula Oblonga
}

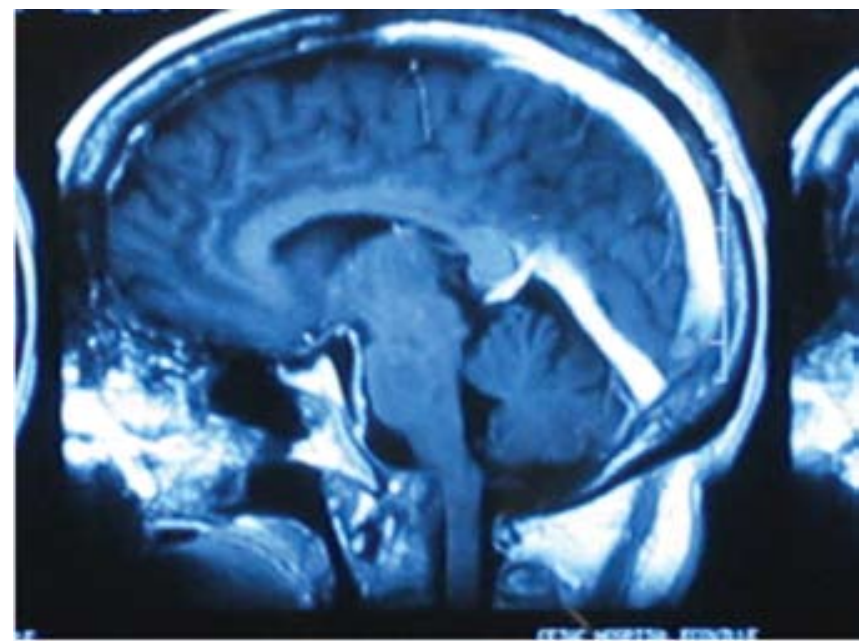

Figura 1 - Ressonância magnética da cabeça.

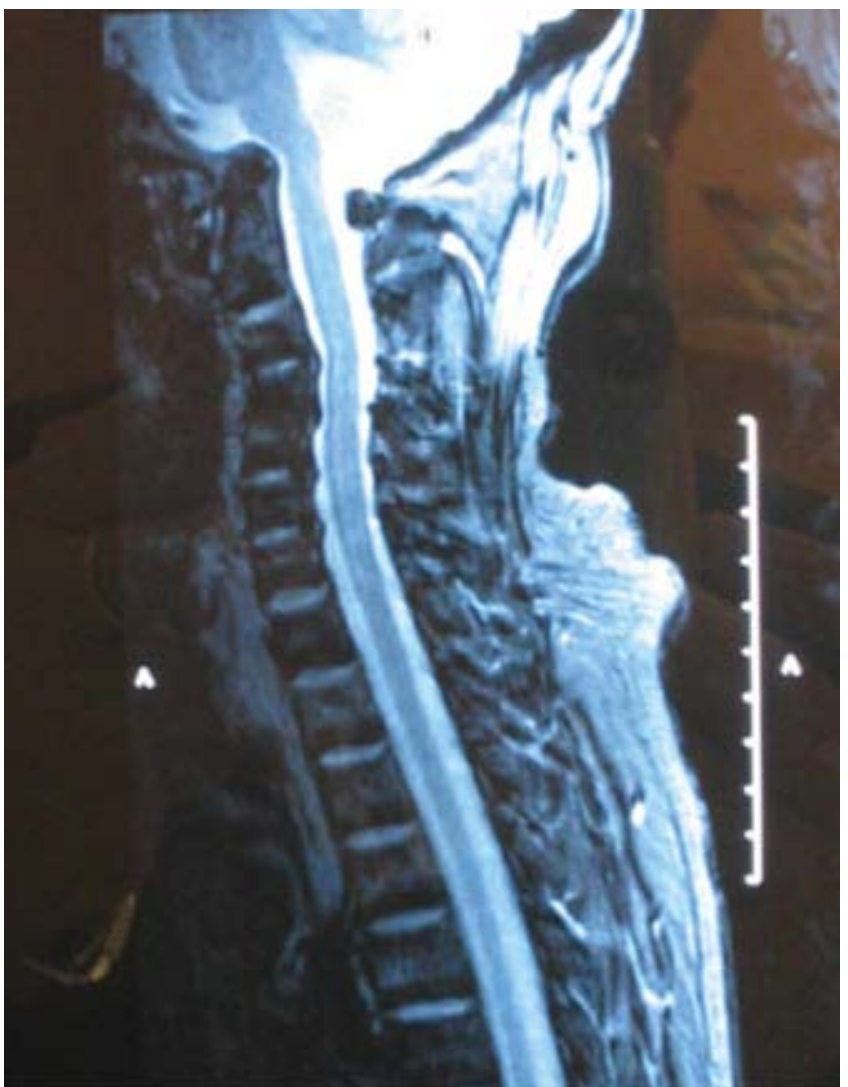

Figura 2 - Ressonância magnética da coluna cervical.

Paciente ES, 58 anos, portadora de artrite reumatóide há 30 anos com seqüelas articulares nas mãos e nos pés, apresentando dor na região cervical constante sem irradiação ou parestesias. Exame neurológico normal. Exames de atividade inflamatória normais. Ressonância magnética de coluna cervical evidenciando compressão medular pelo processo odontóide. Foi avaliada pela ortopedia com plano de cirurgia em virtude da gravidade e da complexidade da situação.

Caso encaminhado por Fernando Augusto Chiuchetta, ex-residente de reumatologia da Universidade Federal do Paraná (UFPR), especialista em reumatologia pela Sociedade Brasileira de Reumatologia (SBR) e orientador de reumatologia para residência de ortopedia do Hospital da XV-Curitiba, PR. Rua Alberto Folloni, 1093 - Curitiba, PR -80540-000, e-mail: fmch8@uol.com.br. 